\title{
EGF-Containing Fibulin-Like Extracellular Matrix Protein 1
}

National Cancer Institute

\section{Source}

National Cancer Institute. EGF-Containing Fibulin-Like Extracellular Matrix Protein 1. NCI Thesaurus. Code C106348.

EGF-containing fibulin-like extracellular matrix protein 1 (493 aa, $~ 55$ kDa) is encoded by the human EFEMP1 gene. This protein is involved in receptor binding. 